\title{
Healthy Subjects Produce both Anti-Factor VIII and Specific Anti-Idiotypic Antibodies
}

Jean Guy Gilles and Jean-Marie R. Saint-Remy

Allergy and Clinical Immunology Unit, Institute of Cellular and Molecular Pathology, Université Catholique de Louvain, 1200 Brussels, Belgium

\begin{abstract}
Anti-Factor VIII (FVIII) antibodies were prepared by a combination of salt precipitation, gel filtration chromatography, and specific adsorption over insolubilized FVIII from the serum of 10 healthy subjects with normal levels of FVIII. Antibody specificity was confirmed by the capacity to recognize soluble and insolubilized FVIII and to neutralize FVIII cofactor activity in FX activation. Epitope mapping was carried out using a competition ELISA in which affinitypurified human antibodies inhibited the binding of labeled monoclonal antibodies. In most cases, a single region of the A3 domain of the FVIII light chain was recognized by the antibodies, while the reactivity toward heavy chain epitopes differed from one antibody preparation to the other. Sera or IgG fractions of the serum before immunoadsorption over insolubilized FVIII did not bind to FVIII. The IgG fraction that was not retained on the FVIII immunosorbent contained IgG that bound to the variable part of anti-FVIII mouse monoclonal antibodies and inhibited the binding of labeled FVIII; in addition, the IgG fraction inhibited the binding of affinity-purified human antibodies to FVIII, thereby strongly suggesting the presence of anti-idiotypic antibodies. These findings indicate that the presence of antiFVIII antibodies is a more universal phenomenon than previously thought and that anti-idiotypic antibodies capable of inhibiting the binding of anti-FVIII antibodies to FVIII are produced spontaneously. (J. Clin. Invest. 1994. 94:14961505.) Key words: Factor VIII inhibitors $\bullet$ immune response - autoantibodies • coagulation • idiotypic regulation
\end{abstract}

\section{Introduction}

Type A hemophilia is an inborn disease of the coagulation pathway and is characterized by a deficiency or dysfunction of Factor VIII (FVIII) ${ }^{1}$ affecting 1 in 10,000 males (1). The clini-

Address correspondence to J.-M. R. Saint-Remy, M.D., Ph.D., Allergy and Clinical Immunology Unit, ICP 7430, 74 avenue Hippocrate, 1200 Brussels, Belgium.

Received for publication 19 October 1993 and in revised form 7 July 1994

1. Abbreviations used in this paper: BBS, borate-buffered saline; FVIII, Factor VIII; FT, flow-through; GBS, glycine-buffered saline; Lx, latex particles; OPD, ortho-phenylenediamine; $r$, recombinant; RT, room temperature.

J. Clin. Invest.

(C) The American Society for Clinical Investigation, Inc.

$0021-9738 / 94 / 10 / 1496 / 10 \quad \$ 2.00$

Volume 94, October 1994, 1496-1505 cal manifestations of the disease include bleeding in the muscles, joints, and soft tissues and are optimally treated by infusions of FVIII. However, such treatment is complicated by the development of antibodies (usually described as "inhibitors") toward FVIII in a variable but significant proportion of the cases (3.6-50\%; references 2-4). The development of inhibitors is particularly prevalent in patients with FVIII levels $<5 \%$ of normal values $(4,5)$.

The occurrence of such anti-FVIII antibodies is a severe complication, which can practically preclude efficient FVIII replacement therapy. Therefore, much effort has been devoted both to improving our understanding of the reasons for the formation of anti-FVIII antibodies and to find alternative methods of treatment. Despite this effort, the mechanisms of production of anti-FVIII antibodies are still largely unknown and treatment is limited nowadays to nonspecific measures such as cytostatic agents, infusions of pooled gammaglobulins (6), or infusions of large amounts of FVIII in an attempt to induce tolerance $(7,8)$.

We recently characterized the anti-FVIII antibody response of hemophiliac patients, a study which included the purification of antibodies by immunoaffinity (9). In the process of validating the immunoadsorption procedure, we included a series of serum samples obtained from healthy subjects with normal levels of FVIII. Unexpectedly, a fraction of antibodies were specifically retained on the FVIII immunosorbent; these could be recovered by elution with dissociating buffers.

Here we present evidence showing that these antibodies are bona fide anti-FVIII antibodies and that their activity cannot be detected before their purification from serum. In addition, the immunoglobulin fraction that is not retained on the column inhibits the binding of anti-FVIII antibodies to FVIII through recognition of their idiotypes.

\section{Methods}

\section{Reagents and buffers}

Human recombinant FVIII (rFVIII) was obtained from Hyland (Glendale, CA) as material for laboratory use only; this preparation contained von Willebrand factor (vWf) but no stabilizer or other protein. $\mathrm{N}$ hydroxysuccinimidyl-LC biotin was purchased from Pierce (Rockford, IL), human serum albumin (HSA) was from Institut Merieux (Lyon, France), and PMSF was from Sigma Chemical Co. (St. Louis, MO). Buffers used were: phosphate-buffered saline, $8 \mathrm{mM}$, pH 7.4 (PBS); PBS containing $0.5 \%$ bovine serum albumin (PBS-BSA); PBS containing $0.1 \%$ Tween 20 (PBS-Tween) (Technicon, Tarrytown, NY); glycine-buffered saline, $270 \mathrm{mM}$, pH 9.2 (GBS); GBS containing $0.5 \%$ BSA (GBS-BSA); borate-buffered saline made of $20 \mathrm{mM}$ boric acid in $150 \mathrm{mM} \mathrm{NaCl}$, adjusted to $\mathrm{pH} 8.1$ with $\mathrm{NaOH}$ (BBS); Tris, $10 \mathrm{mM}$, $\mathrm{pH}$ 7.3; Tris containing $0.5 \%$ casein (Aldrich Chemical Co., Milwaukee, WI) and $0.02 \%$ thimerosal (Sigma Chemical Co.), pH 7.2 (Tris-casein). O'Farrel buffer was made of $62 \mathrm{mM}$ Tris containing $10 \%$ glycerol and $2.3 \%$ sodium dodecyl sulfate ( $\mathrm{SDS}$ ), $\mathrm{pH} 6.8$. 


\section{Blood sample collection}

10 healthy individuals ( 6 males and 4 females) volunteered to participate in the study. FVIII levels were assayed on citrated plasma and ranged from 64 to $128 \%$ of the normal value. Blood was taken by venipuncture and allowed to clot for $2 \mathrm{~h}$ at room temperature (RT). Serum was obtained by centrifugation at $3,000 \mathrm{~g}$ for $15 \mathrm{~min}$ and stored at $-20^{\circ} \mathrm{C}$ until use.

\section{Protein biotinylation}

rFVIII was dialyzed against a solution containing $150 \mathrm{mM} \mathrm{NaCl}$ and $10 \mathrm{mM} \mathrm{CaCl}{ }_{2}$ (wash buffer) and diluted to $360 \mu \mathrm{g} / \mathrm{ml}$ in the same buffer. $100 \mu \mathrm{l}$ of a $10 \mathrm{mg} / \mathrm{ml}$ stock solution of $N$-hydroxysuccinimidylLC-biotin in $150 \mathrm{mM} \mathrm{NaCl}$ was added to $1 \mathrm{ml}$ of rFVIII; the mixture was incubated for $2 \mathrm{~h}$ at $4^{\circ} \mathrm{C}$ and then dialyzed against the wash buffer. Human IgG, or $F\left(a b^{\prime}\right)_{2}$ fragments thereof, were labeled with biotin by the same method except for the use of $500 \mu \mathrm{g} / \mathrm{ml}$ protein and of a 150 $\mathrm{mM} \mathrm{NaCl}$ solution without $\mathrm{CaCl}_{2}$.

\section{Preparation of mouse monoclonal antibodies ( $m A b s)$ to FVIII}

6-wk-old Balb/c mice were immunized with a preparation of human rFVIII suspended in CFA as described previously (9). Hybridomas secreting anti-FVIII antibodies were identified by direct binding to polystyrene plates coated with $2 \mu \mathrm{g} / \mathrm{ml} \mathrm{rFVIII}$ in $50 \mathrm{mM}$ glycine buffer, $\mathrm{pH}$ 9.2. The binding of mouse IgG in the supernatants was detected by the addition of biotin-labeled goat IgG specific for mouse Fc $\gamma$ (Tago, Inc., Burlingame, CA). Positive hybridomas were cloned by limiting dilution and expanded. Antibodies were prepared from the supernatants by salt precipitation and gel filtration chromatography on AcA44 (Pharmacia AB, Uppsala, Sweden).

\section{mAb characterization}

$\operatorname{Ig} G$ and $\operatorname{Ig} G$ subclasses. The concentration and isotype of mAbs were evaluated by ELISA. Polystyrene microtitration plates (Nunc, Roskilde, Denmark) were coated with $50 \mu$ lof an anti-mouse Fc $\gamma$ goat IgG (Tago, Inc.) diluted to $5 \mu \mathrm{g} / \mathrm{ml}$ in PBS and incubated for $2 \mathrm{~h}$ at RT. The plates were then washed four times with PBS-Tween before addition of $50 \mu \mathrm{l}$ Tris-casein for $30 \mathrm{~min}$ at RT. After a second wash, a 50- $\mu \mathrm{l}$ aliquot of $\mathrm{mAb}$ was added, and the plate was incubated for $2 \mathrm{~h}$ at RT. The binding of $\mathrm{mAbs}$ was quantitated by addition of $50 \mu \mathrm{l}$ of peroxidaseconjugated goat IgG specific for mouse Fc $\gamma$ (Sigma Chemical Co.) diluted 1:4,000 in PBS-BSA, followed by $50 \mu$ l of ortho-phenylenediamine (OPD; Sigma Chemical Co.) diluted to $800 \mathrm{mg} /$ liter in citratedphosphate buffer, pH 5. Absorbance was read at $492 \mathrm{~nm}$ in a Kontron SLT-210 spectrophotometer (SLT Lab instruments, Vienna, Austria).

For the determination of IgG subclasses, polystyrene microtitration plates (Nunc) were coated with $50 \mu \mathrm{l}$ affinity-purified human FVIII (Hemofil M; Hyland) diluted to $2 \mu \mathrm{g} / \mathrm{ml}$ in PBS-BSA. After $2 \mathrm{~h}$ at RT, the plates were saturated with $50 \mu \mathrm{l}$ Tris-casein and washed as above. $50 \mu \mathrm{l}$ of the supernatant containing an mAb was added for a 2-h incubation, and the plates were washed again. $50 \mu \mathrm{l}$ of a goat anti-mouse $\mathrm{Fc} \gamma$ biotin-labeled IgG specific to either the IgG1, IgG2a, IgG2b, or IgG3 subclass (all from Amersham, Buckinghamshire, United Kingdom) was added at a 1:5,000, 1:1,000, 1:1,000, 1:2,000 dilution in Triscasein, respectively. After a further wash with PBS-Tween, $50 \mu \mathrm{l}$ of PBS-BSA containing $1 \mu \mathrm{g} / \mathrm{ml}$ avidin-peroxidase was added for $30 \mathrm{~min}$ at RT. The plates were washed again, $50 \mu \mathrm{l}$ of OPD was added, and the reaction was read at $492 \mathrm{~nm}$.

Immunoblotting. rFVIII was digested with thrombin and blotted onto nitrocellulose membranes after SDS-PAGE as described previously (9). Briefly, $2 \mu \mathrm{g}$ of native or thrombin-digested rFVIII was separated on a $4-15 \%$ gel, and proteins were transferred on a $0.2-\mu \mathrm{m}$ porosity nitrocellulose membrane (Machery-Nagel, Düren, Germany); the latter was cut in strips, which were blocked with $3 \%$ gelatine for $30 \mathrm{~min}$ and washed with PBS-Tween. Nitrocellulose strips were then incubated sequentially with $3 \mu \mathrm{g} / \mathrm{ml}$ of a given $\mathrm{mAb}$, a biotin-labeled goat IgG specific for mouse Fc $\gamma$, avidin-peroxidase, and chloronaphtol. The strips were finally rinsed with distilled water.

FVIII inhibitory activity. The capacity of mAbs to neutralize the function of FVIII was evaluated in a clotting assay using the Bethesda method (10) and in a chromogenic assay in which thrombin-activated FVIII acts as a cofactor to Factor IXa in the conversion of Factor $\mathrm{X}$ to Factor Xa, that is measured through its enzymatic action over a colored substrate (Merz \& Dade A.G., Düdingen, Switzerland) (11). Briefly, $35 \mu \mathrm{l}$ of a solution of $150 \mathrm{mM} \mathrm{NaCl}$ containing $10 \mathrm{mM} \mathrm{CaCl}_{2}$ and 100 $\mu \mathrm{g} / \mathrm{ml}$ of the $\mathrm{mAb}$ to be tested was mixed for $30 \mathrm{~min}$ at $37^{\circ} \mathrm{C}$ with 35 $\mu \mathrm{l} \mathrm{rFVIII}$ at a dilution of $150 \mathrm{ng} / \mathrm{ml}$ in the same buffer. $50 \mu \mathrm{l}$ of the sample was then retrieved and mixed with the chromogenic assay reagents, namely, thrombin, phospholipids, FIXa, FX, and substrate, as recommended by the manufacturer. After an incubation of $10 \mathrm{~min}$ at $\mathrm{RT}$, the absorbance was read at $405 \mathrm{~nm}$. Control experiments included rFVIII diluted in buffer without antibodies.

\section{FVIII immunosorbent}

rFVIII was insolubilized by its carbohydrate moieties on a hydrazideactivated solid phase (Affigel-Hz; Bio-Rad Laboratories, Richmond, CA) as described previously (9), with minor modifications. Briefly, human rFVIII was dialyzed against the coupling buffer supplemented with $10 \mathrm{mM} \mathrm{CaCl}{ }_{2}$. HSA and PMSF were added so that the final preparation contained $100 \mu \mathrm{g}$ rFVIII, $5 \mathrm{mg}$ HSA, and $20 \mathrm{mM}$ PMSF per $\mathrm{ml}$. This preparation was oxidized by addition of $100 \mathrm{mM} \mathrm{NaIO}$ for $1 \mathrm{~h}$ at RT, followed by $20 \mathrm{mM}$ glycerol for a further $10 \mathrm{~min}$. Oxidized rFVIII was then dialyzed overnight at $4^{\circ} \mathrm{C}$ against the coupling buffer containing $10 \mathrm{mM} \mathrm{CaCl}_{2}$ and then mixed with a suspension of Affigel- $\mathrm{HZ}$ at a ratio of $1.5 \mathrm{ml}$ per milliliter of packed gel. An immunosorbent was prepared with HSA alone following exactly the same procedure

\section{Preparation of human anti-FVIII antibodies from normal subjects}

Human anti-FVIII antibodies were prepared from serum by salt precipitation, gel filtration chromatography, and adsorption on insolubilized FVIII (9). A 10-ml serum sample was obtained from each patient. Salt precipitation was carried out at $21^{\circ} \mathrm{C}$ by dropwise addition of phosphate buffer, $200 \mathrm{mM}$, pH 8.2, containing $360 \mathrm{~g} /$ liter $\mathrm{Na}_{2} \mathrm{SO}_{4}$. The precipitates were recovered by centrifugation at $8,000 \mathrm{~g}$ for $20 \mathrm{~min}$ after an overnight incubation at RT. The pellets were resuspended in PBS containing $1 \mathrm{M}$ $\mathrm{NaCl}$, and the samples were applied to a $90 \times 5$-cm TSK-HW55 Fractogel (Merck, Darmstadt, Germany) column equilibrated in the same buffer. IgG-containing fractions were pooled, concentrated to $20 \mathrm{ml}$ by ultrafiltration on a YM10 membrane (Amicon, Danvers, MA), and dialyzed against PBS. A 5-ml aliquot of IgG was passed over a 6-ml column of FVIII-Affigel at a flow rate of $10 \mathrm{ml} / \mathrm{h}$. The gel was then washed successively with $100 \mathrm{ml}$ of wash buffer, $20 \mathrm{ml}$ of $400 \mathrm{mM}$ $\mathrm{NaCl}$ containing $40 \mathrm{mM} \mathrm{CaCl}_{2}$ and $25 \mathrm{mM}$ imidazole, and finally 100 $\mathrm{ml}$ of wash buffer. Anti-FVIII antibodies were recovered by sequential elution with acid and alkaline buffers. $20 \mathrm{ml}$ of acid buffer $(50 \mathrm{mM}$ imidazole, $\mathrm{pH} 4.5$, containing $60 \%$ ethyleneglycol, $0.5 \%$ HSA, and 40 $\mathrm{mM} \mathrm{CaCl}{ }_{2}$ ) was passed through the column, followed by $100 \mathrm{ml}$ of wash buffer and $20 \mathrm{ml}$ of alkaline buffer ( $50 \mathrm{mM}$ diethylamine, $\mathrm{pH} 10$, containing $60 \%$ ethyleneglycol and $40 \mathrm{mM} \mathrm{CaCl}{ }_{2}$ ). A final wash was carried out with $100 \mathrm{ml}$ of wash buffer. The fractions eluted from the immunosorbent were adjusted to $\mathrm{pH} 7$ and pooled. Both the immunoglobulin fraction recovered by column elution and containing anti-FVIII antibodies and the flow-through (FT) fraction, possibly containing antiidiotypic antibodies, were dialyzed against the coupling buffer containing $10 \mathrm{mM} \mathrm{CaCl}_{2}$ and stored at $-20^{\circ} \mathrm{C}$ until use. Calcium was added to all antibody preparations for use in assays with soluble FVIII.

Control experiments included the immunoadsorption of purified IgG over an HSA immunosorbent column. Serum samples of 4 of the 10 blood subjects and 4 hemophiliac patients, of whom 2 had high levels of FVIII inhibitors (900 and 170 Bethesda units, respectively), were prepared and passed over the immunoadsorption column exactly as described above. 
In some experiments, FT antibodies were digested by pepsin to generate $F\left(a b^{\prime}\right)_{2}$ fragments. This was carried out as follows: FT was dialyzed against $25 \mathrm{mM}$ sodium acetate buffer, $\mathrm{pH} 4.5$, and adjusted to $1 \mathrm{mg} / \mathrm{ml}$. $1 \mathrm{ml}$ of Pepsin Avidgel (Bioprobe International, Inc., Tustin, $\mathrm{CA}$ ) was added to $2 \mathrm{ml}$ of the immunoglobulin solution. The suspension was incubated for $5 \mathrm{~h}$ at $21^{\circ} \mathrm{C}$ with continuous agitation and then centrifuged for $3 \mathrm{~min}$ at $5,000 \mathrm{~g}$. The supernatant was brought back to neutral $\mathrm{pH}$ by addition of $3 \mathrm{M}$ Tris. Undigested $\mathrm{IgG1}, 2$, 4, and $\mathrm{Fc}$ fragments were eliminated from the solution by passage over protein A-Sepharose (HiTrap protein A; Pharmacia AB). No attempt was made to remove undigested IgG3 antibodies, which are not retained on protein A.

\section{Evaluation of human $\operatorname{Ig} G$ and $\operatorname{IgG}$ subclasses}

The amount of IgG antibodies recovered by affinity purification and their isotype distribution were measured by ELISA as described previously (9). Briefly, polystyrene microtitration plates (Nunc) were coated with anti-human Fc $\gamma$ goat IgG (Tago, Inc.) for $2 \mathrm{~h}$ at RT. The plates were washed, and a 50- $\mu \mathrm{l}$ aliquot of the sample was added for a further $2 \mathrm{~h}$. The binding of IgG antibodies was quantitated by addition of peroxidase-conjugated goat IgG specific for human Fc $\gamma$ (Sigma Chemical Co.) and $50 \mu \mathrm{l} \mathrm{OPD}$, and the plate was read at $492 \mathrm{~nm}$. IgG subclasses were determined on plates coated with an anti-mouse IgG1 rat monoclonal IgG (UCL, Brussels, Belgium), followed by a mouse IgG1 specific to either human IgG1 (Oxoid Ltd., Basingstoke, United Kingdom), IgG2, or IgG3 (both from Calbiochem-Novabiochem, La Jolla, CA). For the determination of IgG4, the corresponding mouse antibody (Calbiochem-Novabiochem) was insolubilized directly on the plate. The sample or a dilution of a standard reference sample (Janssen, Beerse, Belgium) was added, and bound $\mathrm{IgG}$ were detected by addition of a horseradish peroxidase-conjugated goat IgG specific for human Fc $\gamma$ (Sigma Chemical Co.) and OPD.

\section{Qualitative evaluation of antibodies recovered by immunoadsorption}

Affinity-purified antibodies. To evaluate whether the anti-FVIII activity detected in affinity-purified preparations was due to the presence of specific antibodies, the eluates were passed over a column of protein ASepharose (Pharmacia AB). Thus, 500- $\mu \mathrm{l}$ samples of affinity-purified antibodies containing $60 \mu \mathrm{g} / \mathrm{ml}$ of IgG in $20 \mathrm{mM}$ sodium phosphate buffer, $\mathrm{pH}$ 7.0, were loaded on 1-ml protein A-Sepharose columns. The latter was washed with $8 \mathrm{ml}$ of the same buffer, and the FT fraction was concentrated down to $500 \mu \mathrm{l}$ using an Amicon microconcentrator 10 (Amicon). The content of IgG was determined by ELISA as described above ( see evaluation of human IgG). Dilutions of IgG-depleted samples were used in the FVIII assay systems described below.

The presence of antibodies towards $\mathrm{vWf}$ was evaluated using a direct binding ELISA. Polystyrene microtitration plates (Nunc) were incubated overnight at RT with a preparation of highly purified human vWf (kindly provided by Dr. Jef Arnout, Katholieke Universiteit, Leuven, Belgium) that had been diluted to $2 \mu \mathrm{g} / \mathrm{ml}$ in GBS. The binding of $\mathrm{vWf}$ to the plate was verified by addition of a specific mouse $\mathrm{mAb}$ (gift of Dr. Arnout). The plates were washed four times with PBSTween, and a 50- $\mu$ l aliquot of affinity-purified antibodies made at 10 $\mu \mathrm{g} / \mathrm{ml}$ in PBS was added for $2 \mathrm{~h}$ at RT. The plates were then washed as above, and bound IgG were quantitated by addition of $50 \mu \mathrm{l}$ of peroxidase-conjugated goat IgG specific for human Fc $\gamma$ (Sigma Chemical Co.) diluted in PBS-BSA. $2 \mathrm{~h}$ later, the plates were washed as above, before addition of $50 \mu \mathrm{l}$ OPD and reading at $492 \mathrm{~nm}$.

The proportion of anti-FVIII antibodies in the total yield of affinitypurified antibodies was evaluated by measuring their capacity to bind to soluble FVIII. Thus, antibodies were mixed with a preparation of FVIII (Hemofil M) containing vWf and were passed over a column on which anti-vWf antibodies had been insolubilized (9). The proportion of antibodies retained on the column was taken as a measure of relative purity. Rabbit IgG antibodies to human vWf (DAKOPATTS, Copenhagen, Denmark) were oxidized with $\mathrm{NaIO}_{4}$ and coupled to Affigel-HZ essentially as described above for rFVIII. $10 \mathrm{mg}$ of rabbit antibodies was used per milliliter of packed gel. Affinity-purified IgG antibodies of each of the 10 preparations were mixed with Hemofil $\mathrm{M}$ at a ratio of 1:50 (wt/wt) FVIII to antibody for $1 \mathrm{~h}$ at RT. $1 \mathrm{ml}$ of the mixture, containing $2 \mu \mathrm{g}$ antibodies and $40 \mathrm{ng}$ FVIII, was passed over a 6-ml column of anti-vWf immunosorbent. The column was washed with PBS$\mathrm{CaCl}_{2}$, and bound complexes were eluted by passage of $25 \mathrm{ml}$ acid buffer ( $50 \mathrm{mM}$ imidazole, $\mathrm{pH} 4.5$, containing $60 \%$ ethyleneglycol, $0.5 \%$ $\mathrm{HSA}$, and $40 \mathrm{mM} \mathrm{CaCl}_{2}$ ). The eluate and FT fractions of the anti-vWf immunosorbent were dialyzed against $150 \mathrm{mM} \mathrm{NaCl}$ containing 10 $\mathrm{mM} \mathrm{CaCl} 2$ and concentrated by ultrafiltration on a YM10 membrane (Amicon). The IgG content in both fractions was evaluated by ELISA. Control experiments included the substitution of anti-FVIII antibodies by the corresponding FT fraction.

FT fractions. FT fractions were checked for both the presence of FVIII and anti-FVIII antibodies by the chromogenic assay or a latex agglutination assay, respectively, as described below.

\section{Assay systems for human anti-FVIII antibodies}

Agglutination of FVIII-coated latex particles $(L x)$. Biotin-labeled rFVIII was insolubilized on Lx coated with avidin as follows. $50 \mu \mathrm{l}$ of a $10 \%(\mathrm{wt} / \mathrm{vol}$ ) suspension of $0.8 \mu \mathrm{m}$ carboxylated Lx (Estapor K 1080; Rhône-Poulenc, Paris, France) was washed twice in BBS and mixed with $100 \mu \mathrm{l}$ of BBS containing $10 \mathrm{mg} / \mathrm{ml}$ carbodiimide (Sigma Chemical Co.) for $40 \mathrm{~min}$ at RT. Lx was then washed with BBS and centrifuged at $9,000 \mathrm{~g}$ for $5 \mathrm{~min}$; the pellet was resuspended in $200 \mu \mathrm{l}$ BBS containing $50 \mu \mathrm{g}$ avidin (Sigma Chemical Co.) and $50 \mu \mathrm{g}$ BSA. The mixture was incubated for $210 \mathrm{~min}$ at $21^{\circ} \mathrm{C}$ with vigorous shaking. The suspension was then centrifuged and washed successively with GBS-BSA, GBS containing $0.02 \%$ Tween, and GBS-BSA. The final pellet was resuspended in $1 \mathrm{ml}$ of GBS-BSA. $50 \mu \mathrm{g}$ of biotin-labeled rFVIII was added to $500 \mu \mathrm{l}$ of the avidin-Lx suspension, and the mixture was incubated for $60 \mathrm{~min}$ at RT with constant shaking. FVIII-coated Lx (Lx-FVIII) was washed twice with GBS-BSA, and the final pellet was resuspended in $500 \mu \mathrm{l}$ GBS-BSA. For the detection of anti-FVIII antibodies, $20 \mu \mathrm{l}$ of a 1:10 dilution in GBS-BSA of Lx-FVIII was mixed with $20 \mu \mathrm{l}$ of the sample in GBS-BSA; the mixture was then incubated for $45 \mathrm{~min}$ at $37^{\circ} \mathrm{C}$ with constant shaking. Agglutination was then measured by automated particle counting of residual nonagglutinated particles. The concentration of anti-FVIII antibodies in the sample was inversely proportional to the number of free particles.

ELISA. FVIII (Hemofil M) was insolubilized on a polystyrene microtitration plate through $\mathrm{F}\left(\mathrm{ab}^{\prime}\right)_{2}$ fragments of rabbit IgG specific for human vWf, and the binding of anti-FVIII antibodies was detected by addition of peroxidase-labeled goat IgG specific for human Fc $\gamma$ as described (9). Control samples included multi-donor pooled gammaglobulins with no anti-FVIII activity (Gammagard; Hyland) as a substitute for specific antibodies.

Chromogenic assay for FVIII inhibitory activity. This was carried out using the Merz \& Dade chromogenic assay as described above for mAbs (see $m A b$ characterization), but using a FVIII concentration of $400 \mathrm{ng} / \mathrm{ml}$.

Competition between mAbs and human anti-factor VIII antibodies. Polystyrene microtitration plates (Nunc) were coated with rabbit antivWf $\mathrm{F}\left(\mathrm{ab}^{\prime}\right)_{2}$ fragments and Hemofil-M as described above. $50 \mu \mathrm{l}$ of an anti-FVIII mAb diluted to $4 \mu \mathrm{g} / \mathrm{ml}$ in PBS-BSA was mixed with 50 $\mu \mathrm{l}$ of a sample containing a concentration of human anti-FVIII antibodies in the same buffer. $50 \mu \mathrm{l}$ of the mixture was added to FVIII-coated plates for a 2-h incubation at RT. The plates were washed four times with PBS-Tween before addition of $50 \mu \mathrm{l}$ of goat anti-mouse $\mathrm{Fc} \gamma$ biotin-conjugated IgG (Tago, Inc.) diluted 1:4,000 in Tris-casein. The plates were incubated for a further $2 \mathrm{~h}$ at RT and then washed four times before addition of $50 \mu \mathrm{l}$ avidin-peroxidase (Sigma Chemical Co.) made at $1 \mu \mathrm{g} / \mathrm{ml}$ in PBS-BSA. After $30 \mathrm{~min}$ at $21^{\circ} \mathrm{C}$, OPD was added, and the absorbance was read at $492 \mathrm{~nm}$. This intraseries coefficient of variation was $<5 \%$ both for the binding of $\mathrm{mAb}$ and for inhibition by human antibodies. Changes in binding of $>10 \%$ were considered significant. Control experiments included substitution of human antiFVIII antibodies by a preparation of multi-donor pooled gammaglobulins (Gammagard). 


\section{Assay of human anti-idiotypic antibodies}

The detection of anti-idiotypic antibodies was carried out in the IgG fractions from which anti-FVIII antibodies had been eliminated by adsorption (FT fractions). Anti-idiotypic antibodies were evaluated for their capacity to inhibit the binding of labeled FVIII to mAbs, to recognize the variable part of mAbs, or to inhibit the binding of affinitypurified human anti-FVIII antibodies to FVIII.

Inhibition of the binding of labeled rFVIII to mAbs. Polystyrene microtitration plates (Nunc) were coated overnight with $50 \mu \mathrm{l}$ of a given mAb diluted to $2 \mu \mathrm{g} / \mathrm{ml}$ in GBS. $50 \mu \mathrm{l}$ of biotin-labeled rFVIII diluted to $10 \mu \mathrm{g} / \mathrm{ml}$ in Tris-casein was mixed with $50 \mu \mathrm{l}$ of a sample containing anti-idiotypic antibodies, or $\mathrm{F}\left(\mathrm{ab}^{\prime}\right)_{2}$ fragments thereof, adjusted at either 250 or $500 \mu \mathrm{g} / \mathrm{ml}$ in PBS-BSA. A $50-\mu 1$ aliquot of the mixture was added to the plates for an incubation of $2 \mathrm{~h}$ at RT. After washing, avidin-peroxidase and OPD were added as described above. Control experiments included addition of biotin-labeled FVIII in buffer or mixed with a pool of human gammaglobulins.

Binding to anti-FVIII mAbs. Plates were coated with an anti-FVIII $\mathrm{mAb}$ as above. The plates were washed four times in PBS-Tween before addition of $50 \mu$ of FT sample containing $500 \mu \mathrm{g} \mathrm{IgG/ml} \mathrm{in} \mathrm{PBS-BSA}$ for an incubation of $2 \mathrm{~h}$ at RT. Washing was followed by addition of peroxidase-labeled goat IgG specific for human $\mathrm{Fc} \gamma$ (Sigma Chemical Co.), and the binding of human antibodies was detected as described above. Control experiments included plates coated with an $\mathrm{mAb}$ of the same isotype but of unrelated specificity and substitution of anti-idiotypic antibodies by a multi-donor pool of gammaglobulins. Biotin-labeled $\mathrm{F}\left(\mathrm{ab}^{\prime}\right)_{2}$ fragments of FT IgG were also used in this assay. For this, $50 \mu \mathrm{l}$ of a $250-\mu \mathrm{g} / \mathrm{ml}$ protein solution made in PBS was added to the plate, which was incubated for $2 \mathrm{~h}$ at RT. After washing, avidinperoxidase and OPD were added as described above. The binding of $\mathrm{F}\left(\mathrm{ab}^{\prime}\right)_{2}$ fragments was compared with that of the corresponding biotinlabeled FT antibodies.

Inhibition of the binding of human anti-FVIII antibodies to FVIII. Polystyrene plates (Nunc) were coated overnight with rabbit anti-vWf $\mathrm{F}\left(\mathrm{ab}^{\prime}\right)_{2}$ fragments and Hemofil-M as described above. $50 \mu \mathrm{l}$ of human anti-FVIII antibodies diluted to $4 \mu \mathrm{g} / \mathrm{ml}$ in PBS-BSA was mixed with $50 \mu \mathrm{l}$ of a sample containing $500 \mu \mathrm{g} / \mathrm{ml}$ of the corresponding FT fraction made in the same buffer. The mixture was incubated for $2 \mathrm{~h}$ at RT and added in 50- $\mu \mathrm{l}$ aliquots to FVIII-coated plates for a further 2-h incubation at RT. The plates were washed four times with PBS-Tween before addition of peroxidase-labeled goat IgG specific for human Fc $\gamma$ as described (9). Control experiments included the addition of the FT fraction alone.

\section{Statistical analysis}

Correlations between FVIII assays were evaluated by the nonparametric Spearman correlation coefficient test.

\section{Results}

Antibody yield and isotype distribution. IgG antibodies recovered by affinity purification and their isotype distribution were quantitated by ELISA. Table I shows that a significant amount of antibodies was obtained from each of the 10 normal serums, with a mean value of $25 \mu \mathrm{g}$ per $10 \mathrm{mg}$ IgG applied to the immunosorbent. It also shows that the isotype distribution of affinity-purified antibodies closely follows the normal distribution of IgG subclasses, with an elevated IgG4 level in only 3 out of the 10 subjects.

Next, the proportion of specific anti-FVIII antibodies in the affinity-purified IgG fraction was calculated using an assay in which antibodies were mixed with a preparation of soluble FVIII-vWf complexes. As shown in Table I, the proportion of anti-FVIII antibodies combined with the FVIII-vWf complex retained on the anti-vWf immunosorbent ranged from 19 to
Table I. Yield and Subclass Distribution of Affinity-purified Anti-FVIII Antibodies

\begin{tabular}{cccccccc}
\hline & \multirow{2}{*}{$\begin{array}{c}\text { Affinity- } \\
\text { purified } \\
\text { Dontibodies* }\end{array}$} & $\begin{array}{c}\text { Anti-FVIII } \\
\text { antibodies* }\end{array}$ & IgG1 & IgG2 & IgG3 & IgG4 \\
\cline { 6 - 8 } & $\mu g$ & $\%$ & $\mu g$ & & & $\%$ & \\
1 & 15 & 43 & 7 & 58 & 31 & 2 & 9 \\
2 & 19 & 42 & 8 & 64 & 25 & 2 & 9 \\
3 & 30 & 19 & 6 & 53 & 40 & 4 & 3 \\
4 & 19 & 45 & 9 & 56 & 39 & 2 & 3 \\
5 & 23 & 39 & 9 & 37 & 59 & 3 & 1 \\
6 & 35 & 49 & 17 & 59 & 34 & 3 & 4 \\
7 & 16 & 48 & 8 & 48 & 38 & 7 & 7 \\
8 & 24 & 58 & 14 & 49 & 47 & 2 & 2 \\
9 & 23 & 30 & 7 & 60 & 31 & 3 & 5 \\
10 & 44 & 21 & 9 & 36 & 58 & 3 & 3 \\
Mean & 24.8 & 39.4 & 9.4 & 52.1 & 40.2 & 3.1 & 4.6 \\
\hline
\end{tabular}

* Normalized per $10 \mathrm{mg} \mathrm{IgG} \mathrm{applied} \mathrm{to} \mathrm{the} \mathrm{column.}$

$58 \%$, with a mean value of $39 \%$, indicating that at least that proportion of antibodies was specific for FVIII. Control experiments showed that passage over the anti-vWf immunosorbent of FT IgG that had been mixed with soluble FVIII-vWf complexes did not result in any antibody retention. In all subsequent Tables and Figures, data have therefore been corrected for the actual content in specific antibodies.

Assay systems for anti-FVIII antibodies. Three assay systems were used, in which rFVIII was insolubilized by different coupling procedures.

First, affinity-purified antibodies were analyzed for their capacity to bind to insolubilized FVIII. Two different assays were used to this end. The first assay used avidin-coated Lx particles on which biotin-labeled FVIII was bound. This type of binding induces minimal alterations of the three-dimensional conformation of FVIII, as judged by its capacity to bind a panel of mAbs (data not shown). As shown in Table II, at a concentration of $2 \mu \mathrm{g} / \mathrm{ml}, 7$ out of the 10 preparations agglutinated Lx-FVIII. Agglutination was dose dependent and was completely inhibited by addition of soluble FVIII, but not by an unrelated protein such as BSA.

The second assay evaluated the capacity of purified antibodies to recognize FVIII bound to vWf-coated polystyrene plates. Used at a concentration of $4 \mu \mathrm{g} / \mathrm{ml}$, each of the $10 \mathrm{IgG}$ samples significantly bound to the plate, with an absorbance greater than the mean +2 SD obtained with multi-donor pooled gammaglobulins. Representative data for three subjects are given in Fig. 1 , showing that the binding to the plate is dose dependent, while the binding of a 250 -fold higher concentration of pooled gammaglobulins or of the IgG FT fraction is insignificant; the latter indicates that the adsorption procedure depleted essentially all anti-FVIII antibodies from the serum sample. Here again, preincubation of soluble FVIII with specific antibodies completely prevented the binding of antibodies. The percentages of agglutination obtained in the Lx assay correlated significantly with the absorbances obtained in ELISA, using a concentration of $2 \mu \mathrm{g}$ specific antibodies in both cases (Spearman correlation coefficient, $r_{\mathrm{s}}=0.82, P<0.02$ ).

To facilitate the comparison between samples and assays, 
Table II. Qualitative Evaluation of Human Anti-FVIII Antibodies

\begin{tabular}{|c|c|c|c|c|}
\hline \multirow[b]{2}{*}{ Donors } & \multirow{2}{*}{$\begin{array}{c}\text { Latex assay* } \\
\text { (\% agglutination) }\end{array}$} & \multicolumn{2}{|c|}{ Anti-FVIII antibodies } & \multirow[b]{2}{*}{ Clotting test } \\
\hline & & ELISA $^{\ddagger}$ & Chromogenic assay & \\
\hline & & & & $\begin{array}{c}\text { Bethesda } \\
\text { unit }\end{array}$ \\
\hline 1 & 16 & 2.3 & 1.3 & 0 \\
\hline 2 & 5 & $>4$ & 0.1 & 0 \\
\hline 3 & 0 & $>2$ & $>2$ & 0 \\
\hline 4 & 10 & 4 & 0.7 & 0 \\
\hline 5 & 3 & $>4$ & $>4$ & 0 \\
\hline 6 & 57 & 0.3 & 0.3 & 0 \\
\hline 7 & 33 & 0.9 & 2.2 & 0 \\
\hline 8 & 36 & 0.7 & 1.2 & 0 \\
\hline 9 & 21 & 1.9 & 2.6 & 0 \\
\hline 10 & 15 & 0.3 & $>2$ & 0 \\
\hline
\end{tabular}

* Percentage of agglutination using $2 \mu \mathrm{g} / \mathrm{ml}$ specific antibodies. $\quad{ }^{\ddagger}$ Antibody concentration $(\mu \mathrm{g} / \mathrm{ml})$ required to obtain an absorbance of 200 . ${ }^{\S}$ Antibody concentration $(\mu \mathrm{g} / \mathrm{ml})$ required to obtain $20 \%$ inhibition of FVIII activity (see Fig. 2). "Bethesda units measured in serum.

Table II shows the concentration of specific antibodies that was required to generate an absorbance of 0.2 . Three samples did not reach this threshold when used at the maximum concentration of $4 \mu \mathrm{g} / \mathrm{ml}$.

Finally, affinity-purified antibodies were assayed for their capacity to inhibit the function of FVIII in a chromogenic assay. Different concentrations of antibodies were incubated with a predetermined amount of FVIII before addition of the reagents required for the FXa-dependent cleavage of a chromogenic substrate. Fig. 2 shows the dose-response curves for the 10 preparations. It can be seen that in 7 out of the 10 cases a significant inhibition can be obtained. Of interest, a complete inhibition of FVIII activity was observed with four samples used at concentrations of $4.3,2.1,2.3$, and $1.2 \mu \mathrm{g}$ specific antibodies per milliliter, for subjects $1,2,4$, and 6 , respectively, which corresponded to an antibody to FVIII ratio (wt/wt) of $11,5,6$, and 3 , respectively.

Table II lists the concentrations of antibodies that were re- quired to obtain $20 \%$ inhibition of FVIII activity. No significant correlation was found between these concentrations and those needed to obtain a given absorbance in the ELISA system (Spearman correlation coefficient, $r_{\mathrm{s}}=0.26, P=\mathrm{NS}$ ). Table II also contains the results of the evaluation of anti-FVIII antibodies carried out on the initial serum samples. In none of the 10 cases was it possible to detect a significant inhibition, either by a conventional inhibition of coagulation assay $(<0.5$ Bethesda units $/ \mathrm{ml}$ ) or by using the same chromogenic assay as that used for affinity-purified antibodies (data not shown).

Qualitative evaluation of human anti-factor VIII antibod$i e s$. The conclusion that anti-FVIII antibodies are indeed present in the eluates described is strengthened by the following points.

Firstly, eluates were adsorbed on protein A. The FT fractions, which contained on average $<2 \mu \mathrm{g} / \mathrm{ml}$ of IgG antibodies, gave negative results in the three assay systems described above, thus excluding the possibility that the anti-FVIII activity in the eluates was nonantibody in nature.

Secondly, as the eluates contained a proportion of nonspecific antibodies, we determined whether the anti-FVIII activity could be due to antibodies recovered by adsorption on the matrix or on HSA present in the FVIII preparation used for adsorption. Thus, IgG antibodies prepared from the plasma of 4 out of 10 healthy subjects and of 4 hemophiliac patients, 2 of whom have high levels of FVIII inhibitors, were passed over an HSA immunosorbent prepared by the same procedure as for FVIII. An average of $53 \mu \mathrm{g}$ IgG per $10 \mathrm{mg}$ of total IgG antibodies was recovered in the eluates, for hemophiliac patients as well as for healthy subjects. However, these eluates yielded negative results in all the FVIII assays described above. The anti-FVIII activity in the eluates therefore appears to have been specifically adsorbed by the FVIII on the column.

Thirdly, as rFVIII contained vWf and as anti-vWf antibodies could have interfered in the FVIII assays, the presence of anti$\mathrm{vWf}$ antibodies in the eluates was evaluated by use of a direct binding ELISA. It showed that the 10 eluates contained $<10$ $\mathrm{ng} / \mathrm{ml}(<0.1 \%)$ of anti-vWf antibodies.

Mapping of FVIII epitopes recognized by human anti-FVIII antibodies. Mapping of FVIII epitopes was carried out using a competitive assay in which affinity-purified human antibodies competed with a series of mAbs for the binding to FVIII.

Fig. 3 shows the percentage of inhibition of $\mathrm{mAb}$ binding

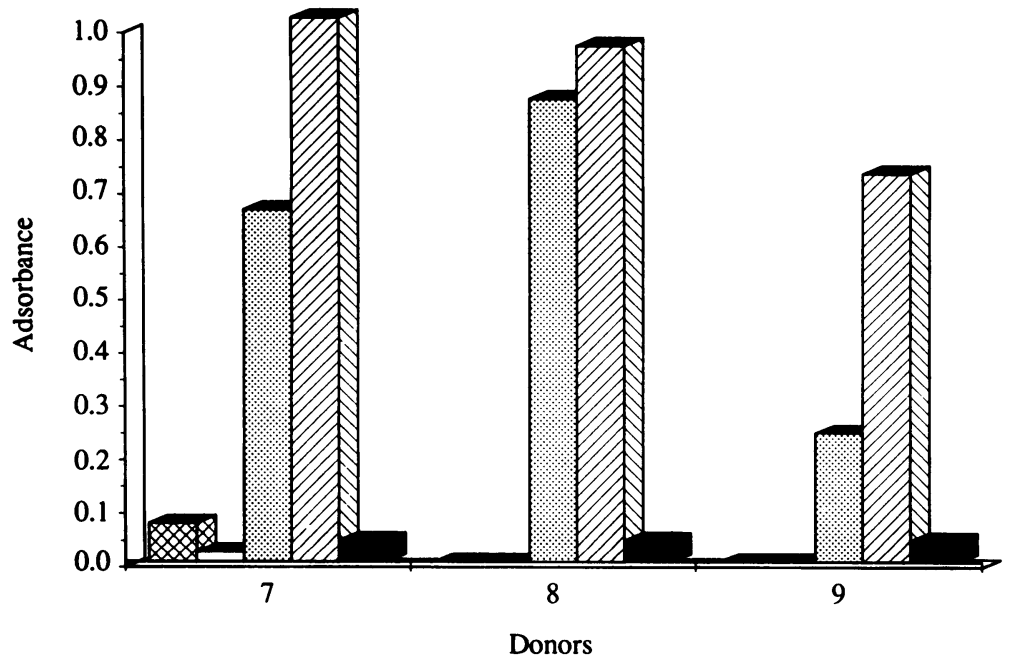

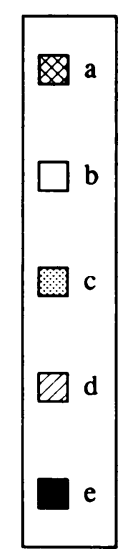

Figure 1 . The capacity of affinity-purified antibodies to recognize FVIII was evaluated in an ELISA in which FVIII was bound to insolubilized $\mathrm{vWf}$. The binding is shown at concentrations of $2(c)$ and $4 \mu \mathrm{g} / \mathrm{ml}(d)$. Control experiments included substitution of specific antibodies by a multi-donor pool of gammaglobulins $(a)$ or IgG FT fraction of the same individual $(b)$, both used at 500 $\mu \mathrm{g} / \mathrm{ml}$. Preincubation of specific antibodies with FVIII was carried out using $10 \mu \mathrm{g}$ soluble FVIII $(e)$. Each test was run in duplicate. Results are illustrated for patients 7,8 , and 9 and are typical of the 10 patients. 


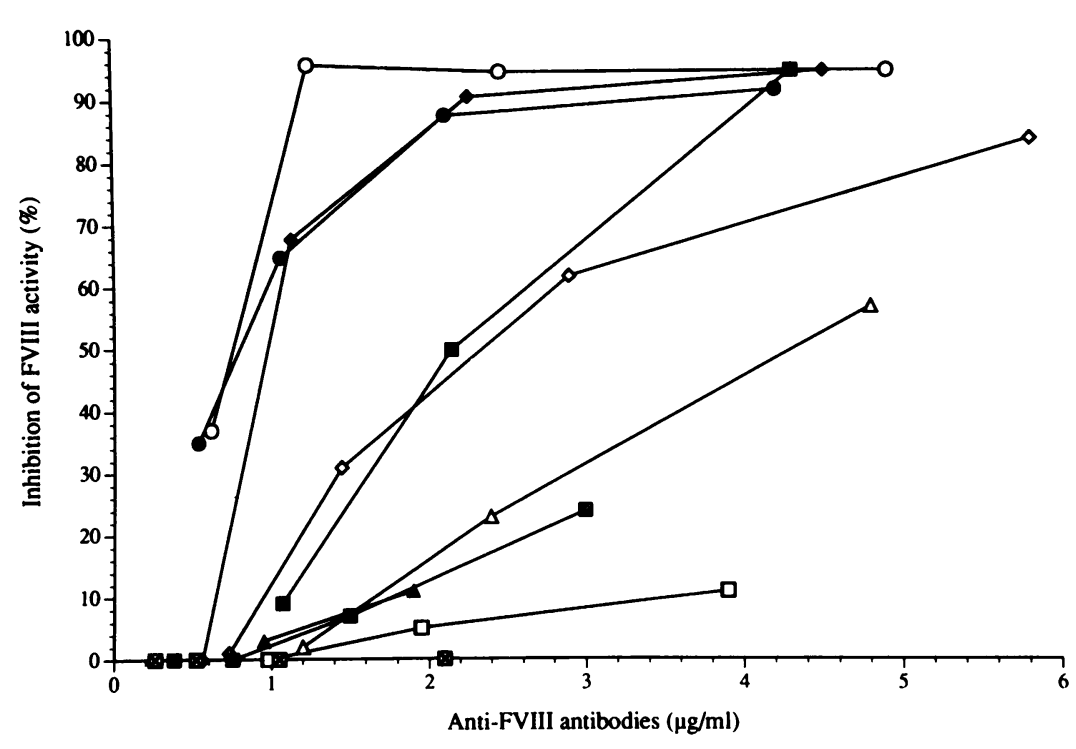

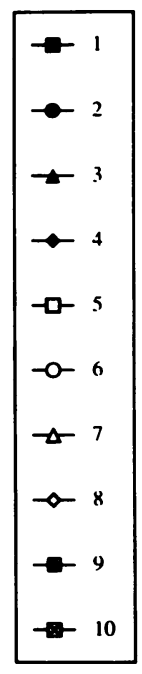

Figure 2. The inhibitory activity of specific antibodies on the functional activity of FVIII was measured in a chromogenic substrate assay. Results are expressed as the percentage loss of FVIII function. Data are given for the 10 subjects. obtained when $4 \mu \mathrm{g} / \mathrm{ml}$ human antibodies was mixed with 2 $\mu \mathrm{g} / \mathrm{ml}$ of a given mAb. Each of the 10 antibody preparations inhibited the binding of at least one mAb. However, the profile of reactivity varied greatly from one patient to the other, indicating the diversity of the anti-FVIII antibody response among normal healthy individuals. Multi-donor pooled gammaglobulins did not inhibit mAb binding to FVIII, indicating that human antibodies did not recognize mAbs or vice versa.

The FVIII epitope defined by $\mathrm{mAb} 13$ predominates in these data. 8 out of the 10 human antibody preparations inhibited mAb 13 binding to FVIII and the mean percentage of competition $(45 \%)$ was the highest of the panel of mAbs. This suggests that a high proportion of normal subjects make antibodies to (or very close to) the sequence delimited by amino acids 1778 and 1871, which is part of the FVIII A3 domain (Gilles, J. G., K. Peerlinck, J. Arnout, J. Vermylen, and J.-M. R. Saint-Remy, manuscript submitted for publication). This preferential presence of an antibody specific for an epitope located on the light chain prompted us to include in the assay four additional $\mathrm{mAbs}$ (ESH1, ESH3, ESH6, and ESH7). All of these four antibodies were partial inhibitors of FVIII activity (9). Five human antibody preparations were used in the competition assay. A significant inhibition was observed for only one of these preparations (No. 7), with mAbs ESH3 and ESH6 (data not shown). Taken together, the data show a great variation of heavy chain epitope recognition, be they functional or nonfunctional epitopes, while the reactivity towards the light chain was essentially restricted to one out of the six epitopes that could be defined with our mAb panel.

Detection of human anti-idiotypic antibodies. Anti-idiotypic antibodies towards anti-FVIII antibodies were assayed for in the IgG FT fractions. First, care was taken that no residual antiFVIII antibodies were left in the IgG FT fractions. No such antibodies were found using the three assays described above. Likewise, use of the chromogenic substrate assay indicated the absence of even small amounts of FVIII, which might have leached from the immunosorbent.

Anti-idiotypic antibodies were detected by their capacity to inhibit the binding of labeled rFVIII to mAbs. Thus, mAbs were insolubilized onto polystyrene plates which were then incubated with biotin-labeled FVIII alone or mixed with one of the IgG FT fractions. Fig. 3 shows the data for the 10 FT fractions and the $8 \mathrm{mAbs}$. As gammaglobulins from a multi-donor pool did not inhibit the binding of FVIII by $>5 \%$ (data not shown), any inhibition above $10 \%$ was considered significant. FT fractions were used at either 250 or $500 \mu \mathrm{g} / \mathrm{ml}$, in each case with a greater binding at the highest antibody concentration, the latter being illustrated in Fig. 3. Identical results were obtained when $\mathrm{F}\left(\mathrm{ab}^{\prime}\right)_{2}$ fragments were used instead of whole antibodies. Three mAbs $(1,7$, and 12) are of particular interest since a significant inhibition of FVIII binding was obtained in 6, 9, and 5 of the 10 cases, respectively. However, we found no obvious correlation between the presence of anti-FVIII antibodies to a given epitope and the presence of corresponding anti-idiotypic antibodies. This particularly applies to mAb 13, which is, as shown above, directed towards a FVIII epitope preferentially recognized by antibodies of healthy subjects.

To confirm that the FT antibodies bound to the variable part of mAbs, their capacity to bind directly to the panel of mAbs was measured. This is shown in Fig. 4; in each case in which FT antibodies inhibited the binding of labeled rFVIII to an $\mathrm{mAb}$, a direct binding to that $\mathrm{mAb}$ was observed, while no such binding was observed for unrelated mAbs of the same isotype.

Lastly, the capacity of FT antibodies to inhibit the binding of the corresponding affinity-purified anti-FVIII antibodies to FVIII was measured using 5 of the 10 antibody preparations. For technical reasons, however, the ratio of anti-FVIII to antiidiotypic antibodies was 10-fold higher in this assay system than the ratio found in the serum. The percentages of inhibition were $26,15,7,38$, and 22 for patients $6,7,8,9$, and 10 , respectively.

\section{Discussion}

We show here that antibodies toward both functional and nonfunctional determinants of the FVIII molecule can be isolated from the plasma of healthy subjects. In addition, an anti-idiotypic activity can be detected, which probably accounts for the fact that anti-FVIII antibodies cannot be identified directly in plasma. 

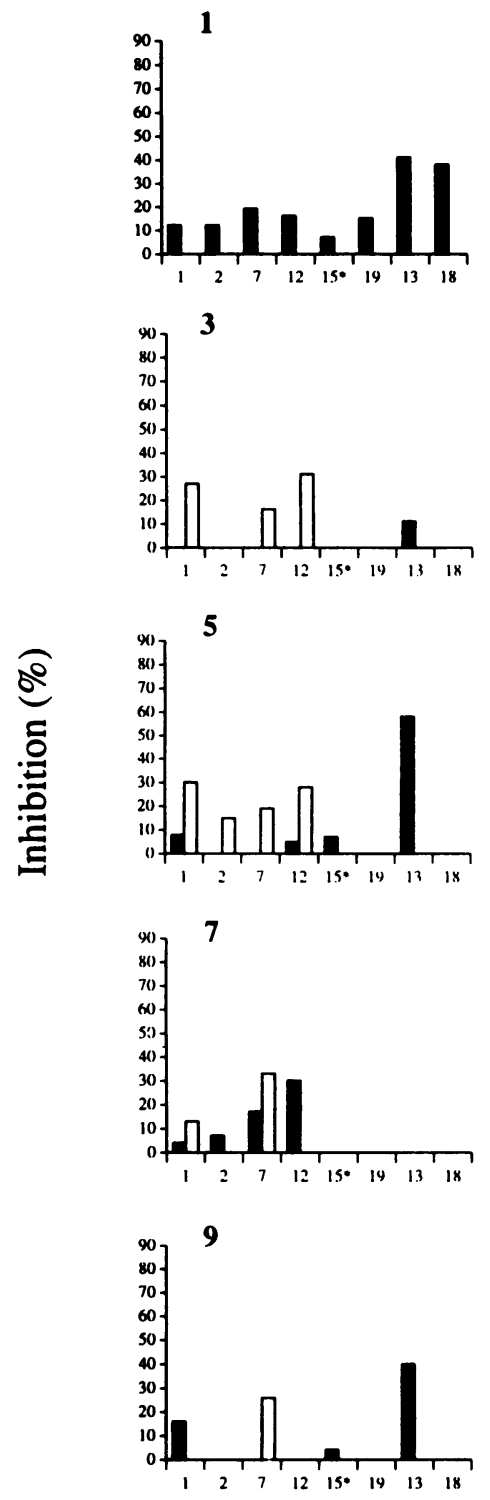
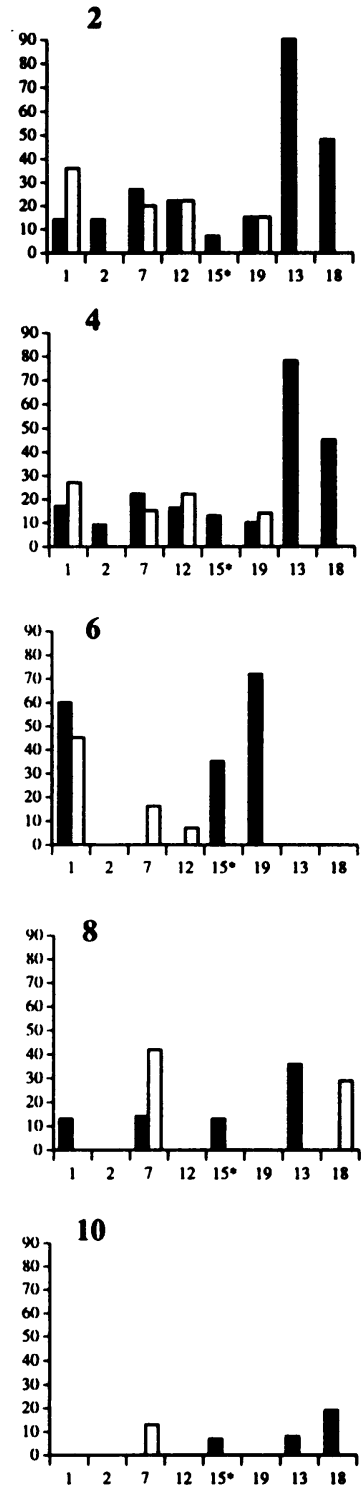

\section{Monoclonal antibody number}

Figure 3. This figure shows individual results of the competition assay between $\mathrm{mAbs}$ and affinity-purified human anti-FVIII antibodies (black bars) and for the inhibition of the binding of biotinlabeled rFVIII to mAbs by human FT antibodies (white bars). For the determination of FVIII epitopes recognized by human affinity-purified antibodies, mAbs specific for either the heavy or the light chains were mixed with specific human antibodies before addition to rFVIII-coated polystyrene plates as described in Methods. The binding of mAbs was detected by addition of an antimouse Fc $\gamma$ goat IgG. To evaluate the capacity of IgG FT fractions to inhibit the binding of biotin-labeled FVIII to mAbs, biotinlabeled rFVIII alone or mixed with an IgG FT fraction was added to the plate as described in Methods. Control experiments included the use of a multi-donor pool of gammaglobulins. Inhibition $>10 \%$ was considered significant. The asterisk identifies an $\mathrm{mAb}$ toward a FVIII heavy-chain functional site.
The immunoaffinity method we described has been used previously for the preparation and characterization of anti-FVIII antibodies made by hemophiliac patients (9). It was shown to effectively deplete specific antibodies from the bulk of nonspecific IgG and to allow for a good recovery of antibodies bound to the immunosorbent. As the immunoadsorption was carried out with a large excess of insolubilized FVIII, we think that the results are probably representative of the situation prevailing in the serum of healthy subjects. That affinity-purified antibodies can be considered as truly specific for FVIII is supported by their capacity to bind soluble FVIII, to recognize FVIII insolubilized by two different methods, and to neutralize the activity of the molecule. In addition, these antibodies specifically inhibited mAb binding to FVIII. This anti-FVIII activity was completely removed by adsorption on protein $\mathrm{A}$, indicating its antibody nature.

The average concentration of anti-FVIII antibodies was 9 $\mu \mathrm{g}$ per $10 \mathrm{mg}$ of total IgG antibodies; this figure should be compared with the average of $140 \mu \mathrm{g}$ that we found in the serum of hemophiliac patients with long-standing inhibitors (9). The isotype distribution of IgG in the eluates resembles that of serum IgG; however, one should consider this with caution, since only $39 \%$ of eluted antibodies bound soluble FVIII molecules. The increased proportion of IgG4 antibodies, which is usually found in hemophiliac patients with long-standing inhibitors $(9,12-$ 14), was observed in only 3 of the 10 samples, including 2 preparations that completely inhibited the function of FVIII. However, we have no direct evidence for a specific role for IgG4 in the neutralization of FVIII activity.

The amount of antibodies that can be prepared by such a method was not closely correlated with their activity in direct FVIII binding assays. Although it cannot be ruled out that this is due to a difference in affinity, a more likely explanation is that some antibody preparations exhibit a restricted epitope 

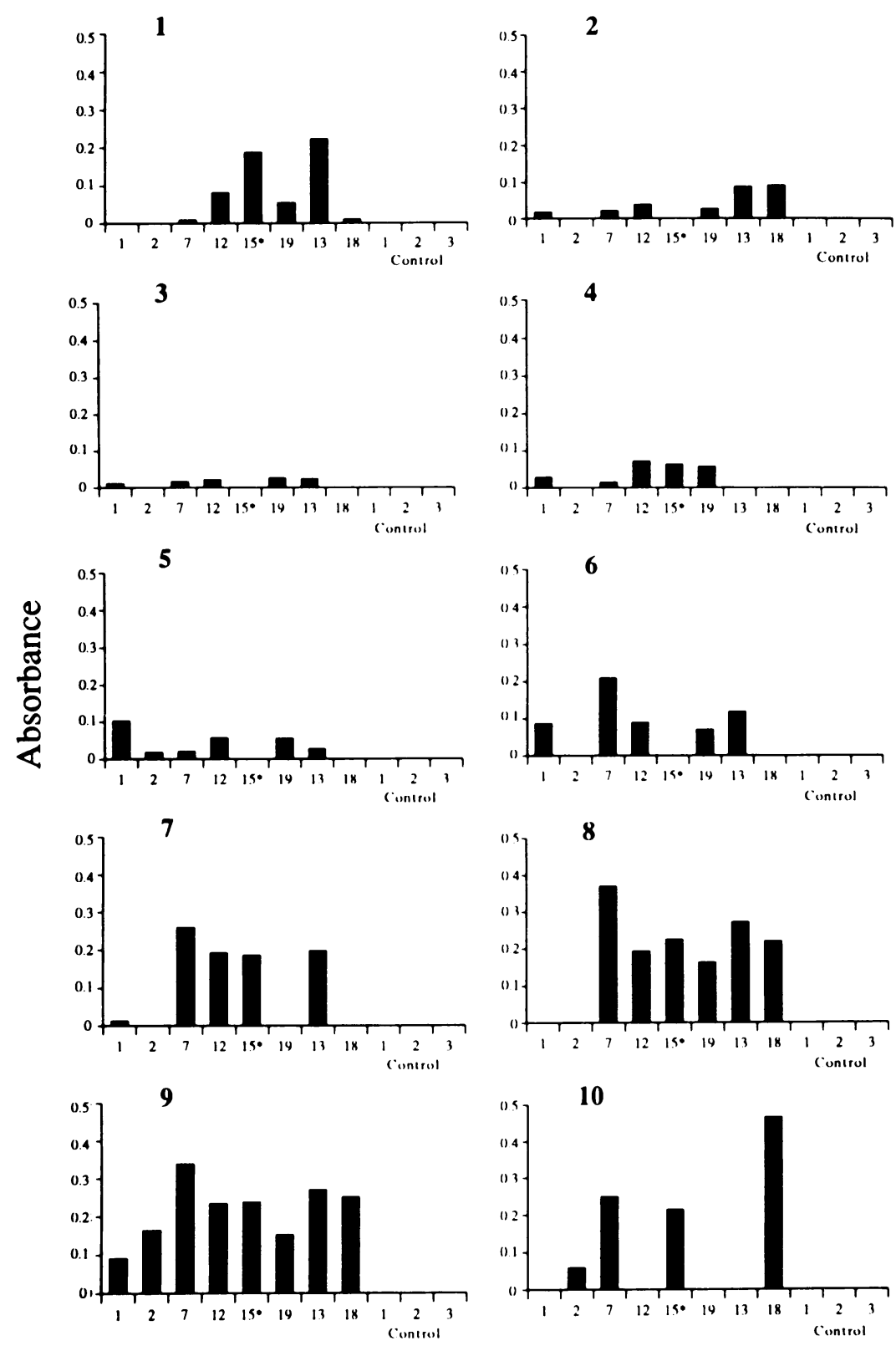

\section{Monoclonal antibody number}
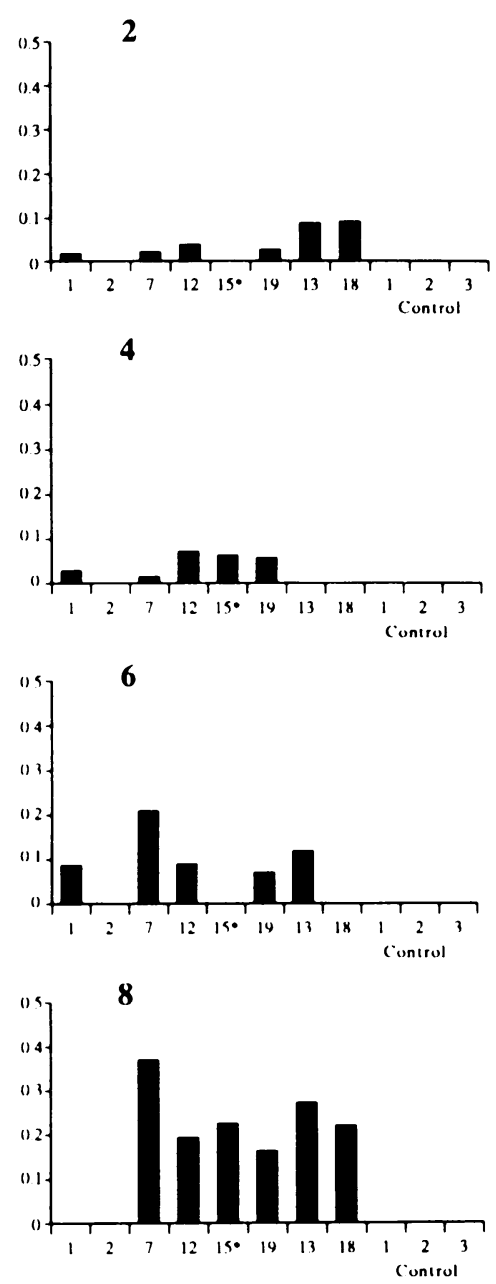

Figure 4. This figure shows individual results of the direct binding of FT fractions to anti-FVIII mAbs insolubilized on polystyrene plates in the absence of FVIII. Plates were coated with $2 \mu \mathrm{g} / \mathrm{ml}$ of $\mathrm{mAb}$, and FT fractions were added at $500 \mu \mathrm{g} / \mathrm{ml}$. The binding of human antibodies was detected by addition of goat anti-human $\mathrm{Fc} \gamma$ peroxidase-labeled IgG. mAbs of unrelated specificities were used as controls: Control I, IgG1: Control 2, IgG2a; Control 3, IgG2b. recognition, as evidenced by the competition assay with mouse mAbs (see samples 3 and 5, for instance). A close correlation was however found between the two FVIII binding assays, which were not strictly related to the functional inhibitory capacity of anti-FVIII antibodies, indicating that these preparations contained a variable proportion of antibodies toward nonfunctional epitopes of FVIII.

Taken together, however, affinity-purified antibodies showed no particular restriction in the number and location of FVIII epitopes recognized. This is very much in agreement with what we found in the serum of hemophiliac patients with known inhibitors (9). The only exception could be the epitope defined by mAb 13 . The question as to whether the preferential recognition of this epitope by most of the antibody preparations of normal subjects has relevance to the function of FVIII is difficult to establish, since the 1778-1871 amino acid region does not contain a site for proteolytic cleavage; it does, however, contain a site for glycosylation, but whether saccharidic moieties can influence FVIII antigenicity is unknown. However, mAbs described by others, and which recognize the same region of the FVIII molecule, have the capacity to inhibit the function of FVIII $(15,16)$.

Anti-FVIII activity was not detectable either in the plasma or in a total IgG fraction from the serum. This is probably not an artifact related to the dilution of anti-FVIII antibodies in the plasma as compared with affinity-purified antibodies. Thus, Fig. 2 indicates that, at a concentration of $3 \mu \mathrm{g} / \mathrm{ml}$, all but 1 of the 10 preparations exhibited a significant inhibition of FVIII activity, while the average concentration in serum was $9.4 \mu \mathrm{g} /$ $\mathrm{ml}$, taking an average plasma $\mathrm{IgG}$ concentration of $10 \mathrm{mg} / \mathrm{ml}$. 
A likely explanation for this lack of detection in the plasma is that anti-FVIII are neutralized by corresponding anti-idiotypic antibodies. We have shown here that fractions of IgG antibodies that were not retained on the FVIII immunosorbent contained antibodies that inhibited FVIII binding to specific mAbs, recognized the variable part of specific mAbs, and inhibited the binding of specific human antibodies to FVIII. The fact that FT fractions did not contain any detectable FVIII or anti-FVIII antibodies, and that FT antibodies exhibited the same activity either in the form of whole antibody molecules or $\mathrm{F}\left(\mathrm{ab}^{\prime}\right)_{2}$ fragments, is evidence for the presence of anti-idiotypic antibodies. The latter are part of the normal immune response in both animals and humans $(17,18)$, and the antibody response toward FVIII seems to be no exception to this rule. Indeed, multi-donor pools of gammaglobulins contain a significant proportion of anti-idiotypic antibodies (19) and the beneficial effect of infusions of pooled gammaglobulins in patients with auto-antiFVIII antibodies has been demonstrated $(20,21)$. As it has been shown recently that the main anti-idiotypic activity to antiFVIII antibodies was carried by IgM antibodies (22), we also searched for such an activity in the IgM fractions obtained from the present healthy subjects, but we failed to find any (data not shown). If the anti-idiotypic activity resided in the IgM fractions, its removal should have revealed the presence of antiFVIII antibodies in the IgG fraction before adsorption; this was not the case.

However, these anti-idiotypic antibodies did not match exactly the specificity of anti-FVIII antibodies, in particular for antibodies directed towards functional sites of the FVIII molecule. We think this may be due to technical differences between the assay used for epitope mapping and that for detection of antiidiotypic antibodies. It is indeed unlikely that $\mathrm{mAbs}$ recognize precisely the same FVIII epitopes as do human antibodies, with the possible exception of $\mathrm{mAb} 13$. In a competition assay where the binding of $\mathrm{mAb}$ to insolubilized FVIII is inhibited by human antibodies, inhibition is influenced by steric hindrance. Human antibodies to epitopes located in the proximity of those recognized by mAbs can at least partly prevent mAb binding. An alternative explanation for the lack of close correlation between anti-idiotypic antibodies and anti-FVIII antibodies could be found in the relatively weaker affinity of specific antibodies for anti-idiotypic antibodies bearing a so-called internal image of the antigen than for the antigen itself. Experiments carried out by using human anti-FVIII antibodies and corresponding antiidiotypic antibodies were unfortunately limited by the respective concentration of these two antibody preparations. It was indeed not feasible to use the solution containing anti-idiotypic antibodies at the same concentration $(10 \mathrm{mg} / \mathrm{ml})$ as that in the serum, which explains why a complete inhibition of the binding to FVIII was not achieved.

The presence in the serum of normal individuals of antibodies directed toward normal serum proteins has already been demonstrated $(23,24)$. The significance of these findings is unknown but it has been suggested that autoantibodies may have a regulatory role (25). With regard to FVIII, the presence of natural anti-FVIII antibodies has been demonstrated in about $17 \%$ of normal subjects, using whole serum in the detection system instead of the purified material prepared here (26).

We observed recently that patients with inhibitors who had been successfully treated by infusions of high doses of FVIII in an attempt to eliminate this undesirable immune response developed high titers of anti-idiotypic antibodies to anti-FVIII inhibitors without significant reduction in the level of antibodies to FVIII (our unpublished data). One might extrapolate from these findings that a method by which anti-idiotypic antibodies towards anti-FVIII antibodies are boosted could be of help in the treatment of patients with inhibitors and represent an alternative to other methods of tolerance induction.

\section{Acknowledgments}

The authors thank Katrien Gilis, Yves Delmarcelle, and Benoît Desqueper for expert technical assistance; Professor J. Vermylen, Dr. Jef Arnout, and Kathelijne Peerlinck for incentive discussions and review of the manuscript; and Brigitte Firket for secretarial help.

\section{References}

1. Foster, P., and T. Zimmerman. 1989. Factor VIII structure and function. Blood Rev. 3:180-190.

2. Schwarzinger, I., I. Pabinger, C. Korninger, F. Hasckke, M. Kundi, H. Niessner, and K. Lechner. 1987. Incidence of inhibitors in patients with severe and moderate hemophilia A treated with factor VIII concentrates. Am. J. Hematol. 24:241-245.

3. Ehrenforth, S., W. Kreuz, I. Sharrer, R. Linde, M. Funk, T. Güngör, B Krackhardt, and B. Kornhuber. 1992. Incidence of factor VIII and factor IX inhibitors in haemophiliacs. Lancet. 339:594-598.

4. McMillan, C. W., S. S. Shapiro, D. Whitehurst, L. W. Hoyer, A. Vijaya Rao, J. Layerson, and the hemophilia study group. 1988. The natural history of factor VIII: $c$ inhibitors in patients with hemophilia A: a national cooperative study. II. Observations on the initial development of factor VIII: $\mathrm{c}$ inhibitors. Blood. 71:344-348.

5. Kavanagh, M. L., C. N. Wood, and J. F. Davidson. 1981. The immunological characterization of human antibodies to factor VIII isolated by immuno-affinity chromatography. Thromb. Haemostasis. 45:60-64.

6. Rossi, F., Y. Sultan, and M. Kazatchkine. 1988. Anti-idiotypes against autoantibodies and alloantibodies to VIII:C (anti-haemophilic factor) are present in therapeutic polyspecific normal immunoglobulins. Clin. Exp. Immunol. 74:311 316.

7. Brackmann, H., F. Etzel, P. Hoffmann, and H. Egli. 1977. The successful treatment of acquired inhibitors against factor VIII. Thromb. Haemostasis. 38:369-375.

8. Van Leeuwen, E., E. Mauser-Bunschoten, P. Van Dijken, A. Kok, E Sjamsoendin-Visser, and J. Sixma. 1986. Disappearance of factor VIII:C antibodies in patients with haemophilia A upon frequent administration of FVIII in intermediate or low dose. Br. J. Haematol. 64:291-297.

9. Gilles, J. G. G., J. Arnout, J. Vermylen, and J. M. R. Saint-Remy. 1993 Anti-Factor VIII antibodies of haemophiliac patients are frequently directed towards non-functional determinants and do not exhibit isotypic restriction. Blood. 82:2452-2461.

10. Kasper, C. K., L. M. Aledort, R. B. Counts, J. R. Edson, J. Fratantone, D. Green, J. W. Hempton, M. N. Hilgartner, J. Lazarson, P. H. Levin, et al. 1975 A more uniform measurement of factor VIII inhibitors. Thromb. Diath. Haemorrh. 34:869-872.

11. Svendsen, L., M. Brogli, G. Lindeberg, and K. Stocker. 1984. Differentiation of thrombin- and factor Xa-related amidolytic activity in plasma by means of synthetic thrombin inhibitor. Thromb. Res. 34:457-464.

12. Scandella, D., M. Mattingly, S. de Graaf, and C. A. Fulcher. 1989. Localization of epitopes for human factor VIII inhibitor antibodies by immunoblotting and antibody neutralization. Blood. 74:1618-1626.

13. Fulcher, C. A. 1991. Immunochemistry of factor VIII:C inhibitor antibodies. Am. J. Med. 91:5A/6S-5A/8S

14. Nilsson, I. M., E. Berntorp, O. Zettervall, and B. Dahlbäck. 1990. Noncoagulation inhibitory factor VIII antibodies after induction of tolerance to factor VIII in hemophilia A patients. Blood. 75:378-383.

15. Stel, H. V., K. S. Sakariassen, B. J. Scholte, E. C. I. Veerman, T. H. van de Kwast, P. G. de Groot, J. J. Sixma, and J. A. van Mourik. 1984. Characterization of 25 monoclonal antibodies to Factor VIII-von Willebrand factor: relationship between ristocetin-induced platelet aggregation and platelet adherence to subendothelium. Blood. 63:1408-1415.

16. Leyte, A., K. Mertens, B. Distel, R. F. Evers, M. J. M. De Keyzer-Nellen M. M. C. L. Groenen-van Dooren, J. De Bruin, H. Pannekoek, J. A. van Mourik, and M. P. Verbeet. 1989. Inhibition of human coagulation factor VIII by monoclonal antibodies. Biochem. J. 263:187-194.

17. Rajewsky, K., and T. Takemori. 1983. Genetics, expression, and function of idiotypes. Annu. Rev. Immunol. 1:569-604.

18. Cunningham-Rundles, C., and M. K. Cheung. 1985. Cross-reacting idiotypes in human sera. Immunol. Today. 6:14-16. 
19. Rossi, F., Y. Sultan, and M. D. Kazatchkine. 1988. Anti-idiotypes against autoantibodies and alloantibodies to VIII:C (anti-haemophilic factor) are present in therapeutic polyspecific normal immunoglobulins. Clin. Exp. Immunol. 74:311 316.

20. Sultan, Y., M. D. Kazatchkine, P. Maisonneuve, and U. F. Nydegger 1984. Anti-idiotypic suppression of auto-antibodies to factor VIII (anti-hemophilic factor) by high dose intravenous gammaglobulin. Lancet. ii:765-768.

21. Zimmerman, R., B. Kommerell, J. Harenberg, W. Eich, K. Rother, and K. L. Schimps. 1985. Intravenous IgG for patients with spontaneous inhibitor to factor VIII. Lancet. i:273-274.

22. Hurez, V., S. V. Kaveri, and M. D. Kazatchkine. 1993. Expression and control of the natural autoreactive IgG repertoire in normal human serum. Eur. J. Immunol. 23:783-789.
23. Avrameas, S., B. Guilbert, and G. Dighiero. 1981. Natural antibodies against tubulin, actin, myoglobulin, thyroglobulin, fetuin, albumin and transferrin are present in normal human sera and monoclonal immunoglobulins from multiple myeloma and Waldenström's macroglobulinemia may express similar antibody specificities. Ann. Immunol. (Inst. Pasteur). 132C:231-236.

24. Rossi, F., and M. D. Kazatchkine. 1989. Antiidiotypes against autoantibodies in pooled normal human polyspecific Ig. J. Immunol. 143:4104-4109.

25. Guilbert, B., G. Dighiero, and S. Avrameas. 1982. Naturally occurring antibodies against nine common antigens in human sera. J. Immunol. 128:27792786.

26. Algiman, M., G. Dietrich, U. E. Nydegger, D. Boeildieu, Y. Sultan, and M. D. Kazatchkine. 1992. Natural antibodies to factor VIII (anti-hemophilic factor) in healthy individuals. Proc. Natl. Acad. Sci. USA. 89:3795-3799. 